Драгољуб Б. Ђорђевић ${ }^{1}$

Унивезитет у Нишу

Машински факултет
Оригинални научни рад

UDK 316.728(=214.58)(497.11)"2018"

Примљено: 06.4.2020.

Ревидирана верзија: 21.5.2020.

Одобрено за штампу: 29.5.2020.

DOI: https://doi.org/10.46630/gsoc.25.2020.02

\title{
ЈОШ СОЦИОЛОШКИХ ЦРТИЦА О ШОФЕРШАЈБНОВЦИМА
}

\begin{abstract}
Ancтракт: Текст је настао на основу истраживања Рома Томислава Асановића, перача шофершајбни на нишкој раскрсници код Моста младости, кога смо преименовали у Тому Семафорџију. Искуствени део проучавања извели су 2018. г. Јелена Динић, Драган Тодоровић и Младен Митровић, док је писац чланка једну деценију скоро свакодневно непосредним посматрањем прикупљао податке о понашању и обављању посла овог шофершајбновца, који се може прогласити за идеалног представника своје занатске феле. Приказујемо, обилато користећи туђи документарни материјал, какав је однос према Ромима перачима шофершајбни, тзв. урбаним рударима у које, поред њих, убрајамо и: амале, бескућнике, ђубраре, задушничаре, збираче старе хартије и кутија, ималинаре, контејнераше, понуђаче ситних израђевина (препродавце), просјаке, сабираче старог гвожђа, сакупљаче боца и ине пластике, смећаре на депонијама, таљигаше, уличне свираче. Иако их се само овлаш дотичемо у социолошком портретисању, очекујемо да ће наше изучавање перача шофершајбни подстаћи скрупулознија емпријска истраживања ромских урбаних рудара, осталих маргиналаца и губитника - не заборавимо - људи који животу дају лепше нијансе, и установљавање социологије беде и пауперизације или социологије маргинализованих група, у српској социологији посебне дисциплине тек у зачетку.
\end{abstract}

Кључне речи: перачи шофершајбни, урбани рудари, Роми Србије, стереотипи о Ромима

Ја живим не радећи, он ради не живећи. Чарлс Буковски

\section{Уводна напомена}

Текст је настао на основу истраживања Томислава Асановића (Слика 1), перача предњег и задњег аутомобилског стакла на нишкој раскрсници код Моста младости, кога смо преименовали у Тому Семафорџију. Искуствени

\footnotetext{
$\overline{{ }^{1} \text { brkab@junis.ni.ac.rs }}$
} 
део проучавања извели су 2018. г. Јелена Динић, Драган Тодоровић и Младен Митровић, док је писац чланка једну деценију скоро свакодневно непосредним посматрањем прикупљао податке о понашању и обављању посла овог шофершајбновца, који се може прогласити за идеалног представника своје занатске феле. До сада су обнародована два рада - Ђорђевић, Д. Б. 2019. „Тома Семафорџија“ (Социолошки преглед LIII4]: 1636-1653); Ђорђевић, Д. Б. 2020. „Урбани рудари Србије: социолошке цртице“, међународна научна конференција Социолошка наука, филозофско и научно знање у функиији прогреса, Филозофски факултет у Никшићу (мај 2020) - а на истеку текуће године биће наштампана и монографија Д. Б. Ђорђевића и Д. Тодоровића Тома Семафориија: сочииолошки портрет перача шофершајбни (Нови Сад, Ниш: Прометеј, Машински факултет).

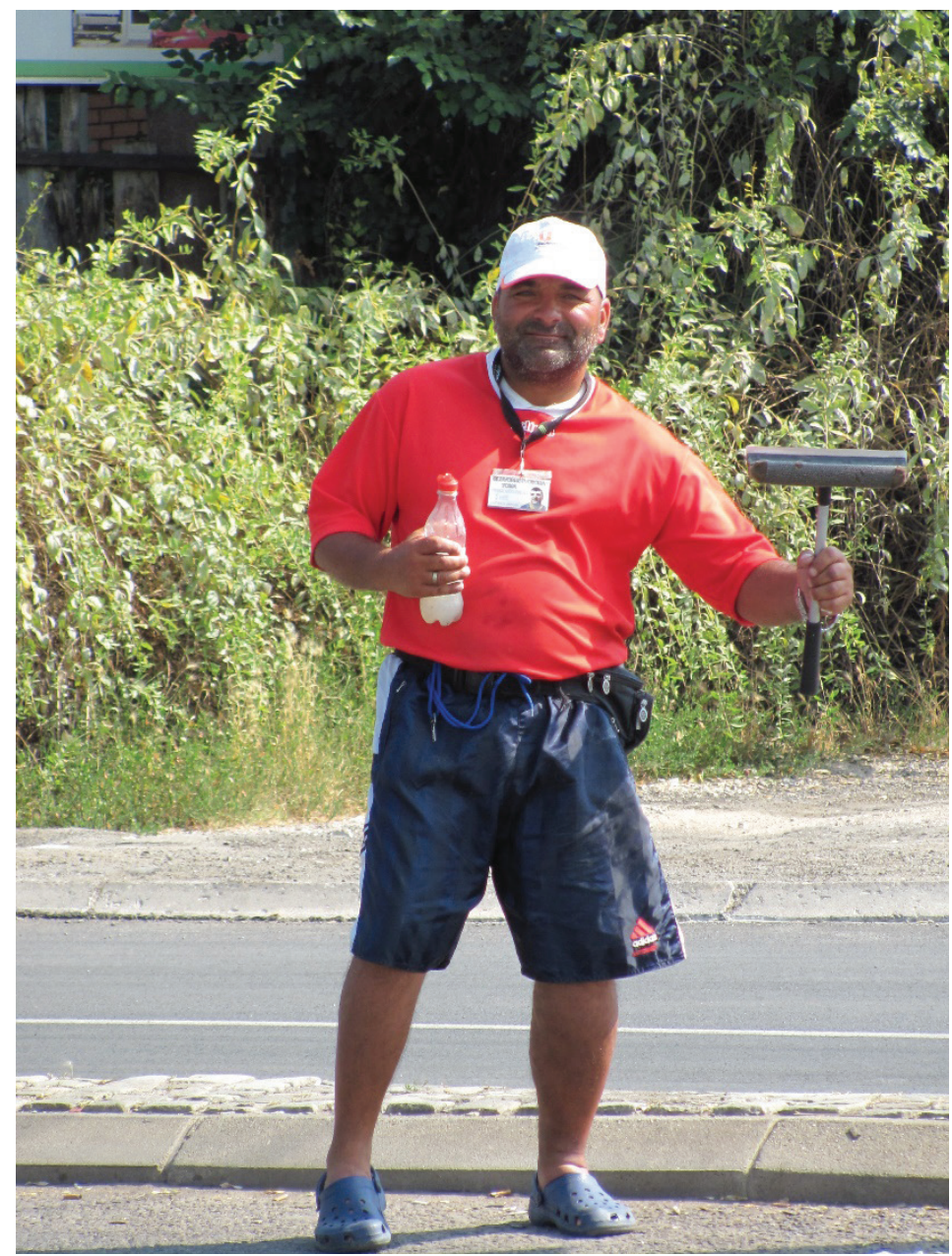

Слика 1: Тома Семафориије (фото: Д. Тодоровић, 2019) 


\section{Семафорџије у окружењу}

Многи Срби су уверени да је прање шофершајбни специјалност српских Рома. Диви им се: Како се само досетише да на још један начин дођу до деньги, измислише, јер су ладолежи и дембели, лаку зараду малтене кроз забаву? Оно, колико се чинило парадоксално, они воле (или су приморани) да се баве пословима које не контролишу Гаџе, што јесте одлика rromanipe-a, и у томе су успешни. ${ }^{2}$ Сетимо се само бувљака у настајању - Ко је с почетка тамо „царовао“?: „Роми се, у тако оштрој конкуренцији, сматрају 'највреднијим' продавцима: одвајкада на маргинама, окружујућим народима су сопствени, проказани стил живота са улица наметнули као образац успешности ван легалних токова привређивања. Они су оличење бувљака - он је 'огледало српске економије “ (Ђорђевић, 2010: 114).

Они нису зачетници перачке работе, која се одавно јавила с првим бензинским постајама и коју и данас на њима успутно обављају точиоци горива или привремено унајмљени омладинци - ђаци и студенти - да би увећали џепарац. Таквих брисача имамо у целом целцатом свету, и у високо развијеним земљама, попут Сједињених Држава, у којима то није тако лоше плаћен посао. (Пишући о нама као купцима скупих „крпица“ у иностранству, луцидни Момо Капор [2018: 21] се чуди: „Како смо дошли до њих, кад су нам плате мање од оних које примају брисачи шофершајбни на њиховим бензинским пумпама?“)

Роми нису покретачи ни гланцања аутомобилских стакала на семафорима. То су, примерице, све донедавно у САД радили Афроамериканци, а сада у Грчкој или Италији избеглице.

Тако испада да српски Роми нису ексклузивци. Њихови истоплеменици из бивших југословенских република више-мање занимају се том активношћу. Моје интересовање за шофершајбновце, захваљујући социолозима из главних градова, слило се у следеће извештаје:

\section{Семафорџија ни за лек у Љубљани и Загребу}

Миран Комац, ${ }^{3}$ Љубљана (Словенија):

- „Побратиме драги, не сећам се да би икад у Љубљани видио такав начин чишћења ауто-стакала. На семафорима сигурно не. Мислим да би одмах интервенирали редари и полиција. Понекад се нађу на бензинским пумпама студенти/студентице, који перу шофершајбне. Раде преко лета или викендом да нешто зараде. А то нису Роми. Распитаћу се код колега и пријатеља да ли се они можда сећају ‘перача ауто-стакала'. Ја сам лично такав начин зараде видео само

\footnotetext{
${ }^{2}$ Више о rromanipe-у у мом уводу у ромолошке студије На коюу с лаптопом у бисагама (2010: 74-95).

${ }^{3}$ Социолог, редовни професор Универзитета у Љубљани.
} 
у Риму и Атини. Само добро желим, Миран“ (From: Miran Komac [mailto:miran.komac@gmail.com] Sent: Sunday, September 02, 2018 3:10 PM To: Dragoljub Djordjevic Subject: Re: Brkina molba).

- „ „Побро, вртим телефон и питам за Роме чистаче прозора на колима. Нико се не сећа чистача уопште. Словенци не познају Роме, веома мало долазе у контакт са њима. За Словенце је све што је тамније 'од здола'. Да поновим, чистача прозора на аутима у Љубљани никада није било! Ни Словенаца, ни Срба, ни Рома. Ако би ико имао такву жељу и интенцију срео би се са полицијом у року од 5 минута. Ја мислим, да то важи и за друге градове. У Атини сам био 78, у Риму 80. и 83-84. Да ли су били чистачи Роми не знам. Мени су деловали као дечаци који желе нешто да зараде“ (From: miran. komac [mailto:miran.komac@gmail.com] Sent: Sunday, September 02, 2018 9:18 PM To: Dragoljub B. Djordjevic Subject: RE: Brkina molba, nanovo).

Иван Маркешић, ${ }^{4}$ Загреб (Хрватска):

- „Било је, али више нема. Нисам их посљедних година примијетио у Загребу. Чинили су то Роми“ (From: Ivan Markešić [mailto:Ivan. Markesic@pilar.hr] Sent: Sunday, September 02, 2018 12:12 PM To: Dragoljub B. Djordjevic Subject: Re: Brkina molba/опет).

\section{Прилично је семафорџија у Сарајеву, Подгорици и Скопљу}

Иван Цвитковић, ${ }^{5}$ Сарајево (БиХ):

- „Рома се могло видјети раније и сада на сарајевским раскрижјима. У Сарајеву, иначе, живи више Рома него у другим градовима Босне и Херцеговине.

Вријеме у Сарајеву зна бити тмурно и магловито, колници мокри (и прљави) па се и шофершајбне брзо упрљају. На градским раскрижјима (код жељезничке станице, Социјалног, у Неџарићима, на Отоци...) стварају се прометне гужве, редови аутомобила чекају на пролаз (или скретање). Згодна је и тад прилика за пераче шофершајбни. Од прољећа до ране јесени. Особито у љетним данима кад је Град пун туриста.

Некад су то радили, углавном, тинејџери из сиромашне ромске популације. Осиромашење друштва довело је до тога да сада међу њима има и припадника неромске популације. Не питајући возача за допуштење, прилазе аутомобилу и чисте шофершајбну. Пластична боца воде и мали ручни џогер и шофершајбна је за неколико десетака секунди очишћена.

Наравно, очекују за урађено и новчану награду. У начелу, буду награђени, најчешће једном конвертабилном марком $(0,5 €)$, мада има и возача који се праве као да се ништа није догодило.

\footnotetext{
${ }^{4}$ Социолог, редовни професор Свеучилишта у Загребу.

${ }^{5}$ Социолог, академик АНУБиХ.
} 
Тешко је процијенити има ли на раскрижјима више младића који чисте шофершајбне или младих Ромкиња са дјететом у наручју које иду од аутомобила до аутомобила, испружене руке, тражећи од возача милодар (или траже новац за храну). Сарајево је град који, према попису становништва из 2013. године, има 341.673 становника (1991 - 429.672) од којих 82,12 \% чине Бошњацимуслимани. Знају Ромкиње да у религијској култури муслимана постоји садака - необвезујући, препоручен начин даривања сиромашних. Особито су руке испружене за садаку петком када је џума (тад се Ромкиње селе с раскрижја у улице ближе џамијама).

У новије вријеме на већим раскрижјима појављују се и одрасли Роми који о врат извјесе прслук на којем су мириси за аутомобиле, папирне марамице чак и цигарете. Нуде то возачима по минимално вишим цијенама него што су цијене тих артикала у радњама.

Ромкиње из нешто боље стојећих обитељи (средње доби), на раскрижјима код Отоке, Социјалног и на мосту Дрвенија, по приступачним цијенама, продају доњи веш (производи из Турске). Газде, чију робу најчешће продају, држе робу у паркираним аутомобилима а изнесу само по неколико примјерака на импровизиране 'штандове' (веће картонске кутије). Кад наиђу полицајци оне се склоне (побјегну иза првог угла зграде), а касније наставе с продајом.

То би, укратко, била слика са сарајевских раскрижја. Сарајево, сијечањ/ јануар 2019. године“ (From: Ivan Cvitkovic [mailto:ivo.cvitkovic@yahoo.com] Sent: Thursday, January 24, 2019 9:04 AM To: Dragoljub B. Djordjevic Subject: Prilog).

Владимир Бакрач, ${ }^{6}$ Подгорица (Црна Гора):

- , „Уважени професоре,

По договору, спремио сам кратак извјештај о 'семафорџијама', који сте тражили.

У пар наврата сам затекао 'семафорџије' у Подгорици (у Никшићу их нема), и разговарао сам са једним, који се у том моменту затекао на семафорима, а за потребе извјештаја који сам спремао за Вас.

Распитао сам се, а и сам са̂м се увјерио да 'семафорџија' има само на једној раскрсници у Подгорици. Уједно, то је и најпрометнија раскрсница у граду, па претпостављам да је та концентрација на најфреквентнијем мјесту, условљена и најбољом зарадом. Раскрсница се налази у близини Римског трга, гдје је лоциран и највећи број министарстава, а недалеко су технички факултети. Дакле, веома фреквентно мјесто, гдје се, у вријеме саобраћајног шпица, дешава да док прођеш семафорску баријеру, возачи чекају и треће зелено свијетло. То нам говори, да 'семафорџије' воле да раде на том мјесту, будући да имају времена за манервисање, без велике журбе.

Колико сам примијетио, ријеч је искључиво о особама ромске популације, махом тинејџерског узраста, од 10 до 17 година, отприлике. Дјечак, са којим сам разговарао, имао је 13 година. Најчешће су мушког пола.

\footnotetext{
${ }^{6}$ Социолог, доцент Универзитета Црне Горе.
} 
У неколико наврата сам посматрао како су примљени од стране возача и утисци су доста дивергентни. Крећу се од љубазног пријема и одобравања, до негодовања. Онолико колико сам ја могао да видим, то негодовање се испољава једноставним затварањем стакла и игнорисањем. Нијесам примијетио да су превише напорни и нападни, али јесу некада навалентни. Када приђу аутомобилу, не питају да ли треба опрати стакла, једноставно приђу и раде свој посао, потом долазе по новац. Примијетио сам, не знам да ли је то Вама интересантно, да се веома често налазе и на паркинг-мјестима, уз тржни центар, помажући људима да нађу паркинг-мјесто, па и за ту услугу траже новац.

Из разговора који сам обавио са дјечаком, сазнао сам да им на семафорима, појединци, за услугу удијеле новац. За прање шофершајбне, појединци им удијеле 0,20-2,00 €. Овдје бих нагласио и један, можда за Вас, интересантан податак. Наиме, људи би можда помогли много више, да не постоји опасност од злоупотребе. Наиме, родитељи их шаљу да зарађују на тај начин, најчешће отац, како би имао новца за алкохол. Због тога су људи врло скептични и неповјерљиви. Чуо сам, али, немам поуздану информацију, да неријетко и раде за некога. Такође, ријетко када прихвате неки поклон (у виду хлеба, или нешто за јело), траже искључиво новац.

Нијесам имао прилику да примијетим да их било ко тјера, па ни полиција. 'Семафорџије' најчешће раде по лошијим временским условима, најчешће по киши, а неријетко и по лијепом времену. Како сам сазнао од дјечака са којим сам разговарао, не раде баш по цијели дан, него у дијелу дана када је саобраћајни шпиц, а неријетко и дуже. Примијетио сам да су ове године знатно ређе на семафору, у односу на раније године, барем до сада. Моја је претпоставка да мала зарада условљава ту промјену, у односу на раније, али, наглашавам, треба пратити како ће се то одвијати током зимских мјесеци. Сазнао сам и још један, мислим, за Вас интересантан податак. Наиме, од дјечака сам сазнао да преко љета нијесу у Подгорици, већ иду за Будву, тамо је, каже, много већа зарада, наравно, током љета и туристичке сезоне. Дакле, током љетњих мјесеци, нијесу у Подгорици.

Сазнао сам и да их има у Тирани, тамо су најчешће преко љета. То је све што сам сазнао.

Толико од мене, ако је потребан још неки податак, биће ми задовољство да помогнем.

Користим прилику да Вам се захвалим на савјетима и сарадњи. Срдачно Вас поздрављам и надам скором виђењу. Поздравите моје драге колеге из НИША“ (From: bvladimir [mailto:bvladimir@t-com.me] Sent: Sunday, December 02, 2018 1:57 PM To: brkab@junis.ni.ac.rs Subject: semafordzije).

Ружица Цацановска, ${ }^{7}$ Скопље (Северна Македонија):

- „Поштовани колега, у Скопљу је некада више некада мање, али у континуитету регистровано присуство Рома, као брисача

\footnotetext{
${ }^{7}$ Социолог, редовни професор на Институту за социолошка и политичко правна истраживања у Скопљу.
} 
шофершајбни... У местима где их има са њима иде и прошење, мајке са децом, итд. Ту су они мало наметљивији да вам избришу шофершајбну и да пошто-пото наплате. Била сам присутна (пре више од десетак година) на једној сцени када је брисач шофершајбни био јако агресиван према жени-возачу која је испред мене стајала на семафору и која вероватно није дала неки динар, или не знам, нагађам... Била је сама, а Ром је био агресиван и ногом је ударио на врата њеног аутомобила. Сличан агресиван испад нисам видела, па се овај случај може сматрати за инцидент. Брисачи обично иду на кола са страним регистарским таблицама, луксузнијим аутомобилима, у нади да би добили надокнаду за свој рад. Обично су брисачи млађи, често и малолетни. То је бриф мојих запажања. Ако било шта треба, фото или слично, само ми пишите. Поздрав из Скопља, Ружица“ (From: Ruzica Cacanovska [mailto:ruzica.cacanovska@gmail.com] Sent: Wednesday, November 14, 2018 12:16 PM To: brkab@junis.ni.ac.rs Subject: Re: Information! Брка).

Поновимо да брисачи аутомобилског стакла на распућу нису српска особеност, већ балканска. Појавили су се у околним државама, ту и тамо опстали, негде су их и затрли. Покушај да се распростру по западним друштвима је осујећен. Пример: Немци к’о Немци, који су Томину браћу по крви и сналажењу „увезли“ уласком Румуније и Бугарске (у којима има дватри, можда и више, милиона Рома) у Европску унију, одлучно су стаклопераче трајно склонили са прометних раскршћа, саобраћајних острва, кружних токова и семафора.

Гле изненађења! Да човек не поверује да гланцера има и у Сједињеним Државама, тој извиканој земљи, у којој су они достигли врхунац 80-их година минулог века у Њујорку. Такозвани сквиџи мен (squeege $e^{8}$ men $)^{9}$ функционисали би тако што би се неколико њих окупило око аута на семафору и најчешће само опрали ветробранску срчу. Ово је додуше често рађено без дозволе, офрље, још би тражили да им се плати, а неретко би и претили возачима разбијањем шофершајбни и сличним стварима. Изгледа да су постали голем проблем, па је 107. градски отац Велике јабуке Руди Ђулијани (Giuliani), који је началствовао од 1. јануара 1994. до 31. децембра 2001, решио да их „почисти“ с распутица и успео је у томе за време свог мандата.

У књизи Вођство ${ }^{10}$, Ђулијани је описао да је његов метод за уклањање шофершајбноваца био хапшење. Перачи које су полицајци хапсили били су пуштани одмах из апсане јер у то време брисање шофершајбни није било незаконито. Како би спречио њихово поновно појављивање на плочницима

\footnotetext{
${ }^{8}$ Сквиџи је алатка за брисање прозора, коју ми просто зовемо брисач.

${ }^{9}$ Постоје различити називи на енглеском говорном подручју. У Канади их зову squeegee kid (дете) или squeegee punk (пробисвет - нарочито у Монтреалу), а у Лондону squeegee merchant (трговац), зато што су нудили и друге ствари поред прања шофершајбни, попут ружа или новина.

${ }^{10}$ Guliani, R. W., Kurson, K. (2002) Leadership. New York: Hyperion.
} 
велеграда, Ђулијани је дао инструкције органима реда да семафорџије хапсе због прелажења улице мимо пешачког прелаза или на црвено светло у недостатку бољег повода. Данас их практично нема на улицама, а ретки случајеви делују као реликвија из давнашњих времена. ${ }^{11}$ (Године 2001. канадски режисер Данијел Крос [Cross] снимио је документарни филм под називом S.P.I.T.: Squeegee Punks in Traffic [Перачи шофершајбни у саобраћају] о перачима у Канади. У филму један од шофершајбноваца који се тим послом бави још од своје 14. године носи са собом камеру и снима свој живот: дневне активности, тешке услове у којима ти клинце живе, константни полицијски прогон, итд. Линк о филму: http://spit.ca/index.main.html. Перачи се могу видети и у следећим филмовима: Suicide Kings - Покер краљьева 1997], The Fugitive Бегунаи [1993], Happy Gilmore - Хепи Гилмор [1996], I’m Gonna Git You Sucka - Имам те, гњидо [1988], итд.).

\section{TC, распутица, семафор и кружни ток}

Да разрешимо бар неку од заблуда које прате пераче стакла на аутима.

Многи возачи, а поготову пешаци, (не)поштујући семафорску сигнализацију, чија су му се правила наизменичне измене зеленог, жутог и црвеног светла претворила у рутину дневног пулсирања урбаног живота, малокад се запита о томе каква је то направа, када настаде, ко је створи и, битније, шта стоји у позадини њеног функционисања. Ко је откривалац аутоматског семафора? Ево сажетог одговора: „Герет Морган * Герет А. Морган, Афроамериканац, изумео је аутоматски семафор 1902. године. Једног дана Морган је присуствовао саобраћајној несрећи у којој су се сударили аутомобил и коњска кола. Овај догађај га је подстакао да направи револуционарну справу, која је до данашњих дана спасла многе животе. Године 1923. патентирао је овај изум, а након тога га продао корпорацији 'Џенерал електрик'. Први семафор, који није био аутоматизован, постављен је испред зграде парламента у Лондону, 1868. године“ (Аноним, 2018б: 30). ${ }^{12}$ Први семафор у Србији је постављен

\footnotetext{
${ }^{11}$ Видети: https://www.nytimes.com/2010/10/04/nyregion/04squeegee.html (превод наслова чланка: Уз брисач [сквиџи и осмех, реликвија разуздане прошлости брише даље) или https://nypost. com/2015/07/19/squeegee-man-is-citys-latest-blast-from-the-past/ (превод наслова чланка: Перачи шофершајбни су последњи градски блесак из прошлости), и кажу да их полиција не дира више (сквиџи мен Џим у другом чланку). Додуше, Њујорк Пост у овом чланку тврди како се њихов број поново повећава: https://nypost.com/2014/08/07/squeegee-men-are-back-and-terrorizing-citystreets/ (превод наслова чланка: Перачи шофершајбни су се вратили и поново тероришу градске улице).

12 „Први семафор је постављен 10. децембра 1868. године у Лондону, а конструисао га је Џон Пик Најт (енгл. John Peake Knight). У то време аутомобили још нису били у употреби, али је саобраћај био оптерећен пешацима и запрегом. То је био механички саобраћајни знак којим је управљао полицајац, и изгледао је као тадашњи семафор за железнице. Имао је обојене траке у црвено и зелено које су показивале да ли је кретање дозвољено или не, а током ноћи су обојене траке осветљавали фењери. Семафором се управљало полугом при постољу семафора, којом
} 
1939. године на раскршћу улица Краља Александра, Краља Фердинанда (данас Кнеза Милоша) и Таковске.

Читава филозофија и њена грана семиотика, која се бави проучавањем знакова, леже иза замисли семафора. Тома Семафорџија, коме је он претпоставка за обављање посла, никада неће апсолвирати да се семиотика дели на семантику (изучава однос између знака и онога што је означено знаком), синтаксу (истражује односе међу знаковима унутар система) и прагматику (проучава релације између знакова и човека који их користи), јер је искуствено стекао знање о томе да је семафор светлосни уређај за регулацију саобраћаја превасходно на раскрижјима, чији је рад дефинисан стандардима (боја, облик и величина светала), да се укључује и искључује одређеним редом, у правилним временским интервалима, те да му се специфичан режим рада зове зелени талас. И да би га требало поштовати без изузетка. ${ }^{13}$

Саобраћајни сигнализациони уређај није само технички новитет изумљен у сврху уређивања промета и спасавања људских живота. Он је задобио још неке функције од којих, сигурни смо, једна није била на памети изуметнику. Њу су, ко би други но Срби, смислили и озваничили. По њима је семафор „душу дао“ за потребе политичке пропаганде. Наши вајни политичари свечано отварају, често уз благосиљање попова, сокачиће и путињке, брвна и мостиће, играонице и кладионице..., па што не и - семафоре. Златко Минић (2018: 6) из НВО „Транспарентност Србија“, дакако иронично, указује на то изливање љубави према народу: „Функционерска кампања је излив блискости према ђацима, пацијентима, градилиштима, семафорима, кравама, зебрама, стипендијама, црвеним тракама, писмима о намерама, који државни функционери на свим нивоима исказују од тренутка када се распишу избори. "14 Уместо што пуштају у саобраћај чак и семафоре - последњи комични пример се одиграо у Краљеву - требало би да се заложе за сиротане и запостављене људе, међу њима и за убоге пераче шофершајбни.

Наравно да нашем делији, Томи Семафорџији, не смета то што се предводници плебса брукају „кадећи“ семафоре; нека се они утркују до миле воље - биће их више, тиме и загарантованог прихода. Шофершајбновац проклиње стање на разделници када су семафори искључени због икаквог квара. Tо се, не знамо зашто, ретко дешава на његовој средокраћи, али се догађа. Тада није могуће обављати хигијенску услугу, Семафорџија се повлачи са раскрсја, скрије у неком за возаче невидљивом кутку, присилно дембелише, чему се не радује - јер губи новце.

Поред те „елементарне непогоде“, његови кваритељи работе су и јаче nадавине: киша и снег. Деси се да му време не буде кооперативно. Да се разумемо,

\footnotetext{
се трака померала тако да буде видљива црвена или зелена. Тај први семафор није радио ни месец дана, 2. јануара 1869. је експлодирао и ранио полицајца који је њиме управљао“ (Семафор [Саобраћај] Википедија, 12. јануар 2019).

${ }_{13}^{13}$ Деси се да функционисање семафора буде пуно лакуна, о чему се може писати и духовито (Andrejić, 2020a: XVI).

${ }^{14}$ Ако друкчије није назначено, сва су подвлачења ауторова.
} 
њега неће омести у обављању посла мрморење кишице или суснежица, али хоће провала облака, кишовина и кијамет - једино тада ће напустити семафор, дреждати испод чандија римске некрополе и чекати да се унормале временске прилике. И да туче туча, удара градушка, Тома Семафорџија је на радном месту - упорно ће истрајавати и нудити услугу - мало попричека док не прође најгоре, и наставља аргатовање. Наравно да трпи и крајњу жегу.

Признајемо да су Томи ине околности наклоњене; он је најуверљивији „власник“" укрштања веома подесног за испирање стакала на четвороточкашима. Оно је тик уз Нишаву, Мост младости, бувљак, пијацу аутомобила, касарну „Књаз Михаило“ и Базилику са мартиријумом. Удаљено на километар од средишта града, у њега се слива Булевар Николе Тесле, којим долази и гро путника из Београда, прелазећи Мост и улазећи Улицом краља Стефана Првовенчаног у строги центар (Слика 2).

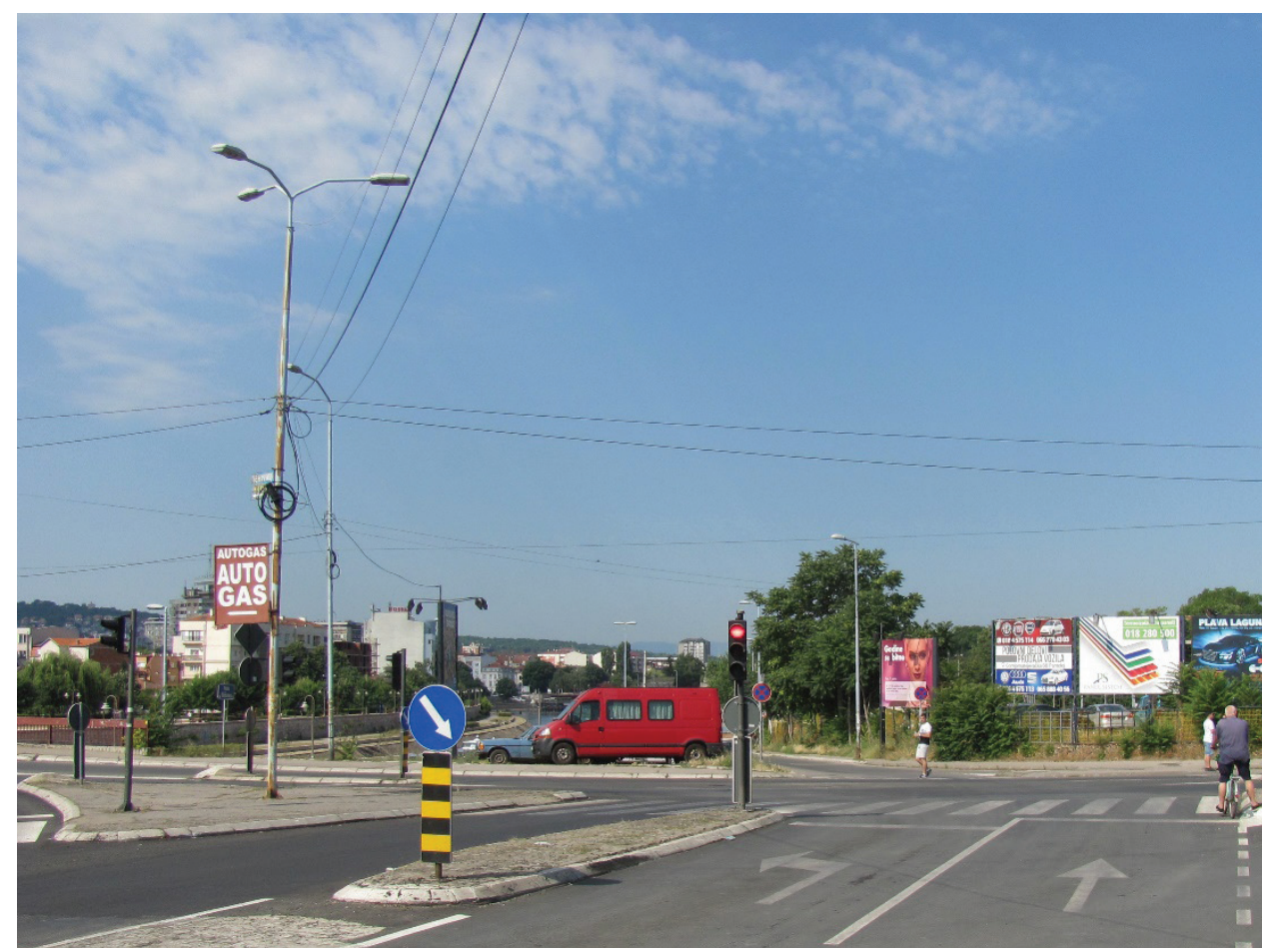

Слика 2: Томино раскршће код Моста младости (фото: Д. Тодоровић, 2019)

Туда пролазе аута и скрећу лево Улицом Ратка Павловића, у наставку Књажевачком, и право за Дервен ${ }^{15}$, Гургусовац ${ }^{16}$ и Неготинску Крајину. Зато је промет врло фреквентан.

Тома Семафорџија прати одвијање саобраћаја и гледа у жмигавце надолазећих кола. Не одговара му десни јер онда људи наврћу у Јадранску

\footnotetext{
${ }^{15}$ Ранији назив Сврљига.

${ }^{16}$ Књажевац се тако звао.
} 
према којој је увек зелено светло и нема заустављања на семафору. Одговара му да мигавци нису упаљени зато што то сигнализира да возач иде право трасом преко Моста младости - и мора да се заустави „на црвено“. Највише се одушевљава ако спази да трепти леви винкер, када ће имати више времена за брисање зато што се аута гомилају у затворену леву траку и чекају да прође семафорски талас према Мосту, који најдуже траје.

Кад нагрну аута и створи се подуг ред, надође навалица аутомобила, Тома не стиже ни да џепницом обрише знојаво чело, грашке му се само сливају низ гараво лице.

Која је највећа, главна опасност за нестанак семафорџија? - Постављање кружних токова.

У Нишу је последњих лета изграђено десетак кружних токова. Само од Ледене Стене до Новог Села има их четири, толико и на Булевару Цара Константина, тј. од Трошарине до Електронске индустрије. Један је при одвајању за аеродром „Цар Константин“, други у Сомборској, два на Булевару Немањића и најновији на Булевару Никола Тесла (Слика 3).

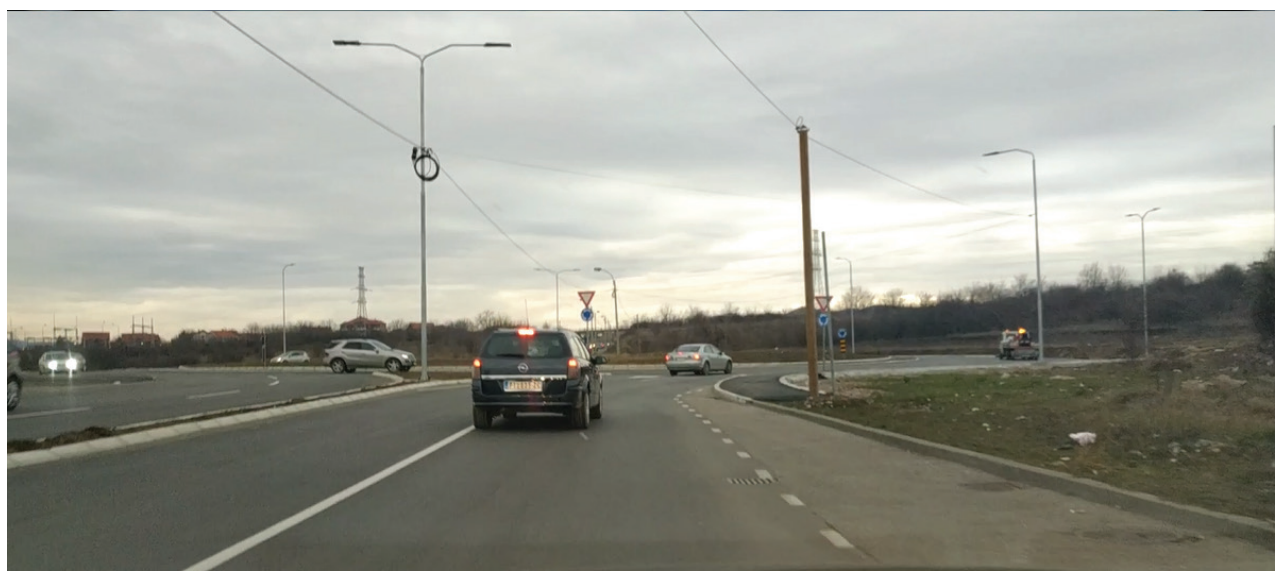

Слика 3: Најновији нишки кружни ток: Булевар Никола Тесла и Булевар Хероји са Котара (фото: В. Петровић, 2020)

Они су очекивано унели више реда у варошки саобраћај. Али, и још једном али, одстранили су пераче као „непотребне“ на кључним тачкама. Прецизније, семафорџије су и те како потребне - довољно је овлаш погледати чистоћу нишких возила - но шта вреди када у условима одвијања промета на кружним токовима, а без семафора, није могуће обављати то специфично занимање. Перспектива је суморна, јер ће остати само два-три раскршћа за перачку работу ако се, како је планирано, у 2020. изгради још шест кружних токова на територији Ниша. Средства су одвојена „(за) изградњу кружних токова у близини Моста младости, на булеварима Сомборском, Никола Тесла, Хероја са Кошара, Медијана и на улазу у насеље Брзи Брод...“ (М., О. 2018: 4). Наш је Тома угрожен - биће уклоњен семафор код Моста младости! 
(Много је сувишних семафора не само на нишким раскрсјима него и у другим градовима.)

Ево цртице о Хусовој улици на престоничком Душановцу:

„Хусова улица, Душановац, Београд. Трошно ромско сокаче крцато бетонским страћарама предвиђеним за рушење - ако се до тада не сруше саме. Испред крзавог кућерка стоји Циганче. Има, по слободној процени, двадесетак година. Обучен је у јакну маскирних боја - сурогат америчке униформе, са све натписом 'U. S. ARMY'. На глави му је јеж фризура, а на челу наочаре за сунце пуног, белог оквира, само - без стакала. Стојећи поред наранџасте кофе, држи ручни брисач ветробрана.

Кроз Хусову пролазе две линије градског превоза, излазећи на 'душановачки мост' - зарђали надвожњак помпезног имена, привремено подигнут за време изградње оближњег аутопута. Било је то седамдесетих година 20. века. Ено га и данас на истом месту. Стоји, клецав, са две саобраћајне траке - у оба смера по једна - и пешачким пасарелама на ободима. Баш као што Хусова, та несуђена 'душановачка петља' ка аутостради, деценијама одолева најавама да ће кроз њу проћи багери.

Седећи у аутобусу који је застао на семафору, спазио сам перача. Хусова је, иначе, узана, па возачи преживе и три 'црвена таласа' док не прођу кроз зелено. Помислио сам да ће Циганче искористити ту прилику и упутити се ка накрцаним аутомобилима. Уместо тога, младић је лежерно одложио брисач у кофу, пуштајући га да потоне. Извадио је 'смартфон', загледавши се у екран. Мој аутобус је кренуо, па опет стао неколико метара даље. Довољно да из видног поља изгубим малог Рома. Осврнуо сам се кроз прозор, покушавајући да га спазим. Угледао сам само наранџасту кофу на тротоару - Димитрије Буквић. “"17

Перачки посао је занат, јесте једноставно занимање као и свако друго и има довољно елемената да га ту уврстимо. ${ }^{18}$ Зашто би точилац горива на бензинској станици, улични чистач ципела или амалин били занимање, а перач не. Е, сад, као што су се многи занати угасили, и овај ће једног дана загаснути. ${ }^{19}$ У земљи Србији проћи ће деценије и деценије док се то деси. Јер:

- инфраструктурно није могуће све распутице са семафорима претворити у кружне токове,

- $\quad$ и да јесте, насељена места немају довољно средстава за ту операцију,

- $\quad$ Роми, као етно класа и примењујући расположиве стратегије преживљавања, тврдокорно - до последњег даха, користиће тај вид самозапошљавања.

\footnotetext{
${ }^{17}$ Посебно написано за наш рад.

${ }^{18}$ Ево и званичне потврде у публикацији Попис становништва, домаћинстава и станова 2011. године: класификачија занимања (2011: 158), у којој се перач шофершајбни води под ознаком 9122.

${ }^{19} \mathrm{O}$ томе опширније у тексту „Запис о занатима и занатлијама“ (Ђорђевић и Тасић, 2015: 99-106). 


\section{Похвале семафорџијама}

Срби имају делимично искривљену слику и затомљену истину о положају Рома (Đorđević, 1998). Иако се формирају и позитивни стереотипи (сналажљиви, отпорни, безбрижни и страствени), те чине добронамерни покушаји да се коренито измени њихов, људски недостојан статус, Роми су и даље дискриминисани у економској, политичкој и културној сфери, подвргнути гетоизацији и сегрегацији, изложени ксенофобији и расизму.

Допадало нам се то или никако, Роми су свугде, па и код нас, од свих етничких заједница далеко изложенији друштвеном удаљавању и предрасудама, ружењу и избегавању (Đorđević, Todorović and Milošević, 2004). Већина их не жели за комшије, суграђане, руководиоце и пајташе на послу, поготово за супружнике - етничка дистанца је врло висока. Потребно је још много времена да истекне како би Срби коначно схватили да битишу у мултиетничком (и мултирасном) и вишеверском друштву: „Живети са и поред расно, етнички и религијски 'друкчијег' јесте предност и богатство - никако несрећа против које се бори и уништавањем живота “ (Ђорђевић, 2013: 39).

Приказујемо, обилато користећи туђи документарни материјал, какав је однос према урбаним рударима у које убрајамо: амале, бескућнике, ђубраре (ЈКП), задушничаре, збираче старе хартије и кутија, ималинаре, контејнераше, пераче шофершајбни, понуђаче ситних израђевина (препродавце), просјаке, сабираче старог гвожђа, сакупљаче боца и ине пластике, смећаре на депонијама, таљигаше, уличне свирце... „Нажалост, све то прате веома типске слике: риљање по депонијама и контејнерима; мусава деца, безуби старци; мали перачи шофершајбни; велике породице збијене по ћумезима...“ (Оташевић, 2008). И да се разумемо, та монотона елегија - синтагма наведене новинџијке - доводи до стварања негативне представе Рома у јавности која је убитачна по њихов идентитет. Зоран Таировић (2015: 214), дискутујући rromanipe - „оно што он у суштини јесте“ (веровања, ставови, култура) - у расправу убацује сасма нови елемент, односно указује на појам „имиџ Рома“ који до сада није довољно узиман у обзир и који није ништа друго но слика коју јавност има о том издржљивом етносу. Он успоставља три могућа односа између идентитета и имиџа:

- Када је имиџ бољи од идентитета, тј. када јавност има бољу слику о неком него што он у ствари јесте,

- Када је идентитет бољи од имиџа, тј. када ромски народ или појединац имају лошију слику у јавности од реалне, и

- Када је идентитет једнак имиџу, што је идеална ситуација. ${ }^{20}$

Да је среће, као што није, rromanipe био био истоветан имиџу. Питање је како се доживљавају шофершајбновци и да ли помажу или одмажу изградњи

\footnotetext{
${ }^{20}$ Видети моју анализу доприноса Шабана Бајрамовића идентитету и имиџу Рома (Ђорђевић, 2018), такође и напис Д. Тодоровића (2008). Консултовати у исту сврху и дискусију процеса њихове протестантизације (Vuković i Todorović, 2020: 261-274).
} 
прихватљиве представе? Једном се похваљују и грађани немају ништа против њих, други пут оштро осуђују све до недоличних изјава, да би се кадшто истицали и инцидентни случајеви, што сводимо на следећи низ: похвале ружења - незгодице.

Тома Семафорџија, наш фаворит међу перачима аутостакала, није усамљени доприносилац њиховом угледу у народу. („На раскрсници код Јагодинмалског моста у Нишу, стакла свакодневно пере на аутомобилима млађи Ром кога сви знају под именом Тома. Он је толико културан и васпитан, да лепо пита да ли може да заради који динар и учини онако како возач жели. Без агресивности, псовки и тешких речи, сви га возачи поштују. Дешавало се да многи отворе прозор, и дају му по 10 или 20 динара, баш зато што тешком муком узима тај динар и то на нормалан и цивилизован начин““ [С., М., 2017].)

Ту је и Аркан Стојковић, Шумадинац „егзотичног“" имена, који ужива неподељене симпатије суграђана и брисач је шоферки већ 33 године. Крагујевчани о њему зборе:

„'Срамота бре, куд иде ова држава? Аркан перач код Парка је најпоштенији и највреднији, и сви га воле - легенда града.' 'Срамота, Аркан је један од перача са раскрснице код Парка - вредан, радан, поштен - сви га воле, легенда града.' ‘За већину њих то стоји, али не за перача са слике. Њега никада нисам чуо да је повисио тон, никада није био навалентан, већину аутомобила препознаје и спреман је да се нашали са сваким од њих, ако немам новца каже: 'Даћеш други пут' - и обрише. Човек је једном речи легенда. P. S. Никада нисам успео да обришем ветробранско стакло онако добро као што он зна да уради.' ‘Аркану свака част, на месту је скроз! Кад немам пара каже: 'Нема везе брате, даћеш кад имаш'. Има и досадних, али бар нешто покушавају. А ово је срамота.' "'21

Даље од следећег примера једва да се може ићи. Новинар „Телеграфа“ у напису с бомбастичним насловом - „Он је највољенији перач шоферки у Србији: Муштерије га облаче, а његовој деци купују књиге!“ - оцртава анонимног семафорџију из непознате вароши ${ }^{22}$ :

„Његова невероватна животна прича неће бити ваљано осликана фотографијама његовог лица, чак ни његовим именом. Он је тако замолио. Има за то ваљане разлоге, рече да неће себи додатно да компликује и овако тежак живот.

Прича о необичној привржености становника једног града, првенствено возача, перачу шофершајбни, изашла је на видело након обичног питања колико је тешко 30 година свакога дана прилазити нервозним возачима 'на црвеном'.

- Тешко? Зашто тешко? Ја никада, али никада нисам ни са ким овде имао проблем, ма ружну реч ми нико од муштерија није рекао за 30

\footnotetext{
${ }^{21}$ (http://ritamgrada.rs/kragujevac/vesti/peraci-sofersajbni-ne-daju-nam-da-radimo-teraju-da krademo/).

22 „Телеграф“ није у потпуности успео да „заштити“ град и шофершајбновца. После вишемесечне потраге расчивијали смо део скривеног - перач је из Крагујевца.
} 
година. И ја поштујем свакога коме приђем. Уљудно питам треба ли прање и не заскачем људе са блиставим шоферкама. Захвалим и за 10 динара најљубазније. А људи су добри. Видиш, ја ни за једно од петоро деце књиге за школу не купујем, све ми народ овде донесе прича овај пожртвовани човек, и наставља.

- Ове патике на мени дала ми је муштерија. Стану на раскрсници, отворе врата аутомобила и пруже ми кесу или џак. Облаче ми и обувају децу. Оно што не могу да донесу, кажу где да дођем и узмем. Знаш ли да ми је веш машина у кући стигла од човека који ме одавде зна, одатле су ми и фрижидер и шпорет. Много је 30 година, за то време добро упознаш човека. А људи ме упознали. Ваљда то што су добри према мени значи да нисам омануо као човек - каже перач шоферки, који је скоро читав радни век провео на истој раскрсници, на месту одакле никада пензију добити неће. Онда показује прстом на пекару испод раскрснице и додаје да му је газда те пекаре само махнуо руком да дође и изнео џак брашна од 25 килограма.

- Власнику оног тамо кафића вратио сам пун новчаник пара његове заборавне муштерије, а он ми већ годинама, када иде на одмор, оставља кључ сефа. Ја му набављам пиће за кафану - каже јунак ове приче и прилази ауту да возачу опере шофершајбну.

Возач се смеје и у тих пола минута на бучној раскрсници 'оптужује' перача да му стално загледа жену у колима, а овај се смешка и одвраћа - ајде реци новинарки, што ме волиш, што сам Циганин или... Возач даје гас, отворено је зелено и уз осмех 'добацује' - волим те бре што си човек!

Перач се враћа на травњак што дели четири саобраћајне траке и чека да се опет укључи црвено. Каже да је на истој раскрсници радио када је она имала две уместо четири траке и када на њој није била ни половина зграда које су сада ту.

- Видиш она црвена кола што долазе, то ти је Славица из Пореске (Слика 4), онај иза је адвокат, одох ево ми га зубар... изговори перач и сунђер на штапу већ опра зубареву шоферку.

У супротној траци прође тракториста и гласно по надимку позва перача. Овај му махањем отпоздрави, и својим путевима, у супротним смеровима, одоше и зубар и сељак, који немају ништа заједничко сем јунака ове приче. И таман када би сваки човек постао неповерљив и када би свако питао - зашто теби дају, то не може бити истина, перач спрема нови шок.

Видиш онај сиви ауто тамо, е он је мој. На силу ми човек дао! Он је познати механичар, ено му је радња друга улица десно испод раскрснице, иди њега питај што ми је дао! Позвао ме и тражио да провозам ауто и кажем му да ли ваља. Седнем у ауто, провозам га, вратим и кажем газди да је ауто добар. Он ми каже - терај га, твој је! Рекао сам ти где је, па провери - каже перач и опет је 'црвено' а он опет на врелом асфалту, пере шоферке и чаврља са људима као да свакога познаје. 
И познаје их, толико да је своје муштерије редом частио када је пре 15-ак година добио првог сина.

'Наш' перач шоферки има петоро деце. На раскрсници му помажу два сина. На дан када је Телеграф имао част да разговара са њим и једним од синова, младић је требало да се спрема за матурско вече. Изузетно културан и скроман дечак оцу је рекао да прослава кошта 1.800 динара, а тим парама породица може да живи три дана.

А перач? Он је успео и као отац“" (R., M., 2016).

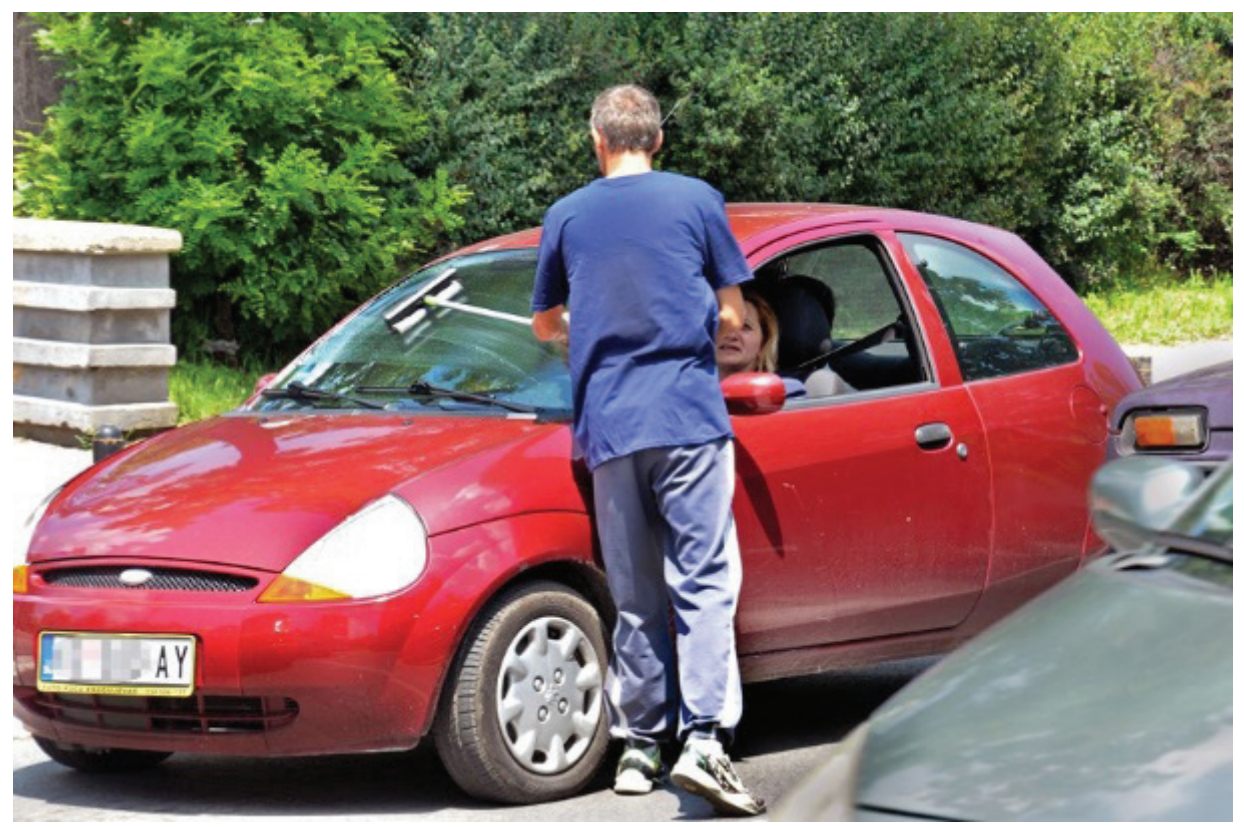

Слика 4: Славица „Порежиијка“ и ,највољенији“" перач

Зашто их шофери воле и поштују и због чега приносе лепшој слици Рома? Зато што су:

- културни,

- васпитани, љубазни у опхођењу,

- веселници, шалџије,

- поштени,

- вредни (бришу и без надокнаде),

- поштоваоци жеља возача,

- мајстори свог заната...

И стога што нису:

- агресивни,

- псовачи,

- грабљивице за узимање пара,

- бездомни,

- просјаци... 


\section{Ружења семафорџија}

Ух, ту је лепеза широка. Већина Томине сабраће се стигматизује, кадикад и чудовишним коментарима. Да погледамо оштре ставове Крагујевчана:

„Навалентни, осорни, груби и спремни да опсују ако им не даш ништа. На моје речи идите нешто да радите, одговорају да нису глупи као ми и да овако више зарађују. То зло, срамоту и ругло треба склонити са улица. Кажеш им НЕ а они то схватају као ДА и почињу да мажу стакло. Када виде да се баш буниш, они онда просе неки динар а ако им кажеш да немаш, они почињу да те псују и беже. У најмању руку су НЕПРИЈАТНИ. Кажу да им не дају да раде и да ће да краду. Ти у животу нису никада подигли нешто теже од 500 грама. Група, неваспитаних и безобразних нерадника.“"23

„- Брат Аркан је ту на раскрници већ 20 и кусур година и добар је и вредан момак. Чињеница је да су они највећи проблем у држави и у граду.

- Доста је вала било - каже возач.

- Овај што држи ову таблу каже да једу само бомбоне - речи једног возача.“ 24

А шта вели једна Томина Нишевљанка:

„Надлежне службе да учине нешто поводом све безобразнијег и агресивног понашања дечака који стоје на средини раскрснице код Суда и буквално искачу испред аутомобила, што да ти перу стакла, што да ти куцају на исти тражећи паре... иритирајуће крајње јер мораш бити посебно обазрив да их не удариш па да одговараш, написала је једна Нишлијка ових дана на свом facebook профилу... Поред њих, врло агресивна је и група која чисти стакла у Улици 7. јули, код цркве Светог Луке. Ако одбијете чишћење стака-

${ }^{23} \mathrm{http} / / /$ ritamgrada.rs/kragujevac/vesti/peraci-sofersajbni-ne-daju-nam-da-radimo-teraju-da krademo/ Вукајлија, хумористички интернет сајт, покушава да буде духовит: „Друга група су стаклари. Ко вози ауто по Београду, нема шансе да бар једном на семафору није видео и чуо легендарно: 'Дај бре батко, што ти прљав стакал, немој се срамотиш пред девојку', да би потом уследило чувено размазивање по шоферци, неке супстанце која личи на воду, а није, и мирише на мокраћу што свакако јесте. Ако сте се увек питали где ови стаклари нађу толико воде за прање толиких шоферки, ето вам одговора. Иза дрвета, у лонце, па на ваше стакло. Ти потези који следе су слични потезима Пабла Пикаса и Ван Гога, то је уметност у малом, трају пар секунди али одишу сјајном лепезом покрета и ритма. Тешко их је избећи јер сте углавном у колони, али и ми возачи смо развили тактику, која се састоји у томе да се не забијете много уз кола која су испред вас, него оставите мало више места, па кад се стаклар затрчи са својим воденим оружјем, ви само мало гас и добили сте битку. Али само битку, пошто вас на следећем семафору чека следећи стаклар ратник. Врло су тешки за обрачун јер користе најубојитије оружје, такозвану психолошку замку, наиме он вам као пере прозоре и очекује да ви то цените и да дате својих омиљених 20 динџи које сте оставили за сутрашњи Курир. Значи чиста замка, као не траже ништа за џабе, него као раде. Са њима нема зајебавања, неће вам помоћи ни што сте управо опрали ауто последњим остацима плате, а ни што журите код таште у посету. Они посао морају да одраде и да буду плаћени. У малој сте предности ако возите опасан ауто, по могућности неки џип, јер се тада и они мало заплаше, па по принципу боље да живим још мало, прескачу скупе аутомобиле поготово ако им возач истог упути зајебан поглед. Можете и ви да пробате са зајебаним погледом, ал сумњам да ће успети, поготово ако возите неки раскантани југо или не дај Боже форд ескорт.“ Гледано 19. септембра 2018.

${ }^{24} \mathrm{http} / /$ ritamgrada.rs/kragujevac/vesti/peraci-sofersajbni-ne-daju-nam-da-radimo-teraju-da krademo/ 
ла, обавезно вам добаце ‘дај нешто ситно’. Када и то одбијете, следи псовка. Поједини возачи, колико видим, укључују брисаче, да спрече прање стакала, али то је потпуно ненормално. И шта се догађа, и када им одмахнете руком 'да не бришу', ипак то чине на брзину и додају 'дај нешто ситно, опрао сам ти стакла'. Све то није проблем да се догоди једном или два пута, али ако сваки дан месецима имате исту борбу са њима, онда то заиста није нормално - прича ова Нишлијка.“"25

Њој се у ружењу шофершајбноваца придружују још оштрији критичари: „-- Проблем је одавно ескалирао, тако да касни овај коментар. Угрожавање саобраћаја, полиције ни од корова, па се питам - треба ли нешто трагично да се деси ‘перачима' или возачима и да се проблем реши?

- Какве су шансе возача, да нпр. отворе задња врата и седну на задње седиште? Код цркве Свети Лука 'перачи су врло:

- пунолетни,

- агресивни, и

- арогантни, нарочито према женама...

- Мени један од њих није хтео да узме 15 дин., колико сам имала ситно тренутно, као неће ни да узме толико мало.

- На прву лопту човеку буде жао и сажали се када види ситну децу која покушавају да на поштен начин заради неки динар. Истина је у ствари тотално другачија. Та деца су ту по задатку, раде за родитеље и шефа њихове банде, све је то део уигране екипе. Као перу шофершајбне, а у ствари покушавају да вас покраду. Ту исту децу можете видети викендом испред Куће за венчање како просе и џепаре!!! Све ово што пишем, пишем из свог личног искуства јер су и мене једном приликом изџепарили. Од тада више немам ни трунку сажаљења, то је једна уиграна екипа и добро позната органима власти, али на велику жалост закон је на њиховој страни и зато драги моји суграђани чувајте се!!!

- Исти ови код Суда после 'смене' са тим новцем који зараде иду у казино. Две трећине просјака у Нишу проси да би се коцкало а приче о болесним члановима породице су бесмислене. “26

Нека је и тако, социолог би, стајући у одбрану одистинских перача шоферки, па и малолетника, требало да их разграничи од деце убожника и разјасни двоумицу. Да, у Нишу после укидања свратишта на калдрми има нешто ромских малишана, јадничића који просе. Та „деца улице“, препуштена сама себи, користе и укрштања за сналажење и успутно покушавају да буду и перачи. Утврђено је, међутим, да већина жицкароша, који припадају влашким Ромима, ${ }^{27}$ није из Наисуса, већ да контролисано долази из алексиначког села Прћиловица. Онда је социолошки оправдано разликовати:

\footnotetext{
${ }_{25}$ http://www.gradjanin.rs/decaci-koji-peru-sofersajbne-sve-bezobrazniji-iznudjuju-novac/ На овом сајту је и веома духовита одбрана малих гланцера: „Реците, слободно мали Цигани су дрски и напињу лење возаче на раскрсницама. Зашто 'лење', па зато што не перу своје шофершајбне! Да их перу онда мали Цигани не би били навалентни, јер вероватно нису ћорави!“ „Мени не засмићу, немам паре за гориво да се шврћкам и бахатим.“ „Па иди и пери шофершајбне...?!““

${ }^{26} \mathrm{http} / / / w w w . g r a d j a n i n . r s / d e c a c i-k o j i-p e r u-s o f e r s a j b n e-s v e-b e z o b r a z n i j i-i z n u d j u j u-n o v a c /$

${ }^{27}$ Тихомир Ђорђевић је класификовао Роме по томе одакле су дошли на Беле, Мађарске, Турске и Влашке. Погледати покушај да се уведе и тип „Српски Ром“ (Ђорђевић, 2018).
} 
- злостављану дещу, у коју спадају и она приморана на изнуђивање, и

- ангажовану децу, у коју улазе и стаклоперачи.

Малтретирани малолетници јесу деца улице - ангажовани то никако нису. Док Ана Саћиповић, предводница нишлијског Удружења Ромкиња „Освит“, правилно мисли - „Они који се баве прањем шофершајбни такође се не могу звати децом улице, јер они имају јавно пријављене адресе на којима живе са својим родитељима.“ - дотле Адријана Аметовић из НВО „Понос““ греши када, за разлику од јавне прошње малолетника, прање шоферки на семафорима сврстава у скривено просјачење слабомоћне деце. ${ }^{28}$

Истинабог, бројни су малодобни перачи ветробрана на колима у нашим градовима. Уместо да су деца у школи, а младићи на послу, ето њих на раскршћима.

Изгледа да их је спрам одраслих највише у престоници. ${ }^{29}$ Зато прво иде J. Д. Љутића (2012) запис из Београда „Како је бити перач шофершајбни са градских улица“:

„МУСАВЕ девојчице и дечаци на прометним раскрсницама, са сунђерима и кантицама у рукама, спремни да на брзину оперу шофершајбну за ситнину, свакодневни су 'декор' и проблем Београда. Колико их је, нико поуздано не може да каже, као ни да тачно процени колико година имају. Почев од оних старијих и агресивнијих, до оних од 15, 10, али и само пет година.

Тринаестогодишњи Е. Г. је један од најпознатијих београдских 'гланцера' Тврди да овај посао ради из љубави, али и да би зарадио који динар.

- Перем шоферке већ неколико година - прича Е. Г. - Од зарађеног новца, а то је у просеку око хиљаду динара, живи цела моја породица. Боље и то него да крадем, пљачкам... Зими је напорно, али када дође лето, то је права 'бања'. Радим сваки дан са колегом код Пионирског парка. Ту нам је ‘база'. Само када пада киша, одмарам. Имам и ја душу...

Е. Г. каже да никада никог није присиљавао да му плати за урађен посао, нити је тражио милостињу.

ЗА ПРОСЈАЧЕЊЕ 20.000 ИЛИ ЗАТВОР. Није редак случај да млада мајка, или пак бака са бебом у рукама, прилази возачима и тражи новац.

- Ово се већ може подвести под просјачење, за шта се изриче прекршајна казна од 20.000 динара до месец дана затвора - објашњава Старчевићева. С обзиром на то да је у питању и занемаривање и злоупотреба детета, постоји и

\footnotetext{
${ }_{28} \mathrm{http} / / /$ www.radiocity.rs/program/projekti/pravo-na-pravo/deca-uluce/1664/borba-za-egzistencijuili-radna-eksploatacija.html

29 „На прометној раскрсници код Дома Народне скупштине јуче је царевао, наизглед, уобичајен призор. Непрегледни низ четвоточкаша праћен хором аутомобилских сирена опслуживали су дежурни момци са сунђерима и четкама у рукама. Кад год ухвате црвено светло на семафору, као стрелци иду у потрагу за запрљаном шофершајбном... Осим на тромеђи Булевара краља Александра, Таковске и Кнеза Милоша, бусије су заузели и у Балканској улици, на Аутокоманди, Зеленом венцу...“ (Буквић, 2009: 14) Д. Буквић, новинар „Политике“, у истом тексту описује Роме који на великим и ударним престоничким раскрсницама нуде возачима разноразне дрангулије, посебно флуоресцентне прслуке.
} 
кривична одговорност, а казна је од три месеца до пет година затвора.

- Ово је посао као сваки други, није то просјачење. Неки људи нам плате 10, неки 30 динара, а неки не дају ништа. Не љутим се, нема народ пара. Лепим девојкама хоћу и за џабе да оперем сва стакла на ауту, не само шоферку.

Полиција их често тера са раскрсница, некад и кажњава.

- Некад побегнемо, а некад нас ухвате... И онда опомињу, терају нас, пишу казне. Али, одакле да платим? Наљутим се, бацим канту и сунђер, опсујем, одем... Сутра кад устанем, видим да немам где и поново, на улицу и на посао - каже Е. Г.

ПОЛИЦИЈА: НИЈЕ КАЖҢИВО ПО ЗАКОНУ. Драгана Старчевић, инспектор Одељења за јавни ред и мир ПУ Београд, објашњава да се прање шофершајбни на раскрсницама не сматра прекршајем по закону о јавном реду и миру.

- Ово би било кажњиво само кад би се утврдило да се неко лице, које ради овај посао, истовремено бави и просјачењем. Истина, линија је јако танка... Децу која перу шоферке на посао углавном шаљу родитељи и скоро по правилу реч је о Ромима.

СВАКО ИМА 'СВОЈ' ПОРОДИЧНИ СЕМАФОР. Најчешћи насртаји перача шофершајбни су на раскрсници код Скупштине, па на Аутокоманди, код Сава центра, 'Делта ситија', на углу Краљице Марије и Кнеза Милоша...

- Углавном се зна ко ради на којој локацији, али има и премештаја каже инспектор Драгана Старечевић. Свако има 'свој' семафор и 'држи' га годинама... Чак се неке раскрснице и породично 'наслеђују', са оца на сина, са старијег на млађег брата, жену, девојку..."

А затим цртица „Да т’ оперем кола?“, која се појавила на сајту МОНДА ${ }^{30} 12$. јануара 2010:

„Друштвени проблем, или пак још један у низу типичних београдских призора који овом граду дају његов јединствен шмек? Неке нервирају, некима су симпатични, али и лети и зими, по киши и ветру, они су увек ту: перачи шофершајбни. Екипа МОНДА кренула је да сазна како изгледа њихов живот.

На раскрсници код Скупштине, наша екипа упознала је малолетне момке, Мохамеда и Фердија. Сусрет испрва није кренуо најбоље - нису били задовољни што смо им прање платили само неколико десетина динара, иако је то стандардна цена. Видели су камеру и очекивали више. 'Брука!', рекао је Мохамед и незадовољно бацио новчаницу назад у ауто.

Ипак, успели смо да се упознамо и да се мало дружимо. Кажу да им се овај посао исплати и да нису истините приче да раде за друге, старије газде којима морају да плаћају 'рекет’. Зараде и до 1.500 динара дневно. 'Зашто бих ја свој новац дао неком другом? Радим за себе', каже Мохамед.

Новац троши на храну, пиће, изласке и, најрадије, на гардеробу. А воли да се облачи попут репера са МТВ-а. Ферди каже да воли да слуша 50 Сента (50 Cent), Шон Пола (Sean Paul) и Ашера (Usher), па није чудо што воле да ђускају. А колико добро то раде, можете да видите у видео прилогу.

\footnotetext{
${ }^{30} \mathrm{http} / / /$ mondo.rs/a159090/Info/Drustvo/Da-t-operem-kola-VIDEO-prica-o-peracima.html
} 
Жао им је што не иду у школу, уточиште проналазе у свратишту, а детињство као да им је одавно прошло. Ипак, и даље чувају осмех на лицу. Када се у јавности покрене прича о томе ко је одговоран за ову децу, из центара за социјални рад увек стижу иста објашњења: ма колико пута покушавали да их изведу на 'прави пут', некако се увек враћају на улицу.“

\section{Семафорџијске незгодице}

Било би претерано тврдити да је све потаман међу шофершајбновцима.

Добро де, као у икојем послу, не може се ни очекивати да сви буду на високом нивоу - исправни професионалци попут Томе Семафорџије чије се занимање не своди строго на рутинско чишћење предњег и задњег стакла лимузине и извисује се за два копља изнад камаре брисача.

Такви, који су залутали у стаклоперачку работу, у пролазу су с наканом да штогод искамче, на брзину окористе - несвесни чињенице да се чистачи ветробрана не могу умилионити - извор су разноврсних, лакших и тешких, незгодација. Јесте да их убоштина, мусавосива свакодневица тера на друм, на раскрсје с четком и кантицом у рукама, али их због неискуства и неопрезности доводи у ситуацију да угрожавају сопствене и туђе животе - понекад изазивају прометне несреће. („'Пре свега у праву сте да има доста злоупотреба деце, доста повређивања. У току прошле године смо имали два баш озбиљна случаја повређивања деце на раскрсници, деце која су прала шофершајбне. То јесте велики проблем, то њихово кретање по саобраћајницама, поготово у време шпица и градске гужве представља велики проблем и за возаче који морају додатно да пазе на њих, а и за њих саме и њихову безбедност. И имали смо као што рекох неколико забележених драстичних случајева са тешким телесним повредама, на срећу не и са смртним последицама. Наравно да ја никада нећу да кажем, нити да прихватим чињеницу да је то проблем који не може да се реши и да ту не може да се нађе неко трајније или прикладније решење', рекао је Братислав Тимотијевић.“ - Шеф одсека за малолетничку делинквенцију при нишкој полицији. ${ }^{31}$ )

Него ништа мање невоља није ни кад се назовиперачи, а заправо полукриминалци или малодобни делинквенти, супроставе закону, насрну на полицајца или наруше здравље невиних људи. Наводимо примере из престонице и Константиновог града.

У Београду се шофершајбновац, ни мање ни више, пошакетао с чуварем реда и мира: „Саобраћајни полицајац В. Б. (32), који регулише саобраћај на раскрсници улица Булевар краља Александра и Кнеза Милоша нападнут је у среду око поднева од стране уличног перача.

Како портал Гласа јавности незванично сазнаје на њега је насрнуо А. К. (22) који је после упозорења напао саобраћајца, када је одбио да се легитимише и ударио га песницом у главу и огребао по руци.

31 http://www.radiocity.rs/program/projekti/pravo-na-pravo/deca-uluce/1664/borba-za-egzistencijuili-radna-eksploatacija.html 
Према првим информацијама мотив напада на саобраћајца био је у одбијању да се А. К. и остали улични перачи склоне са улице, а када је полицајац затражио личну карту, А. К. га је напао и ударио.“ (Екипа „Гласа јавности“, 10. август 2011) 32 Други случај није тек обична догодовштина, већ крупан идиотлук у којем је могао недужни човек да изгуби вид. Како пише Б. Јаначковић (2018):

„Један путник из Ниша завршио је на Очној клиници Клиничког центра у Нишу након што су га малолетници који перу шофершајбне испрскали по очима течношћу којом перу стакла на возилима.

Инцидент се десио данас око 13.50 часова у Вождовој улици у центру Ниша у аутобусу превозника 'Ariva litas' на линији Чалије-Бубањ.

- Аутобус је стајао на семафору на раскрсници код Палате правде. Један од малолетника који перу стакла прснуо је течност кроз луфтер на бочном стаклу и попрскао по очима једног путника. Путник је позвао Хитну помоћ због пецкања очију и затражио да сиђе у Улици Генерала Милојка Лешјанина - каже наш извор. Срђан Цекић, руководилац пословне јединице ‘Arrive’ у Нишу каже да је путник затражио да сиђе из аутобуса како би потражило лекарску помоћ.

- Ово је први такав случај у нашим аутобусима - потврдио је Цекић за 'Блиц'.

Како незванично сазнајемо, путник је превезен на Очну клинику ради прегледа, а аутобус са осталим путницима је наставио да вози на линији.

О инциденту је обавештено Основно јавно тужилаштво у Нишу.

- Дежурни тужилац је обавештен да је једна особа примљена у болницу па је наложио полицији да прикупи потребна обавештења о овом случају како би се утврдило има ли елемената кривичног дела - каже портпарол Основног јавног тужилаштва у Нишу Милица Јововић.“"33

Напослетку да човек не поверује, али је жива истина: гланцери могу бити солидарни, знају да се удруже када их мука присили - као да су апсолвирали своја „синдикална“ права - чак и да протестују све до штрајка глађу.

Протест је 16. августа 2016. године, под геслом „Хоћемо да радимо, нећемо да крадемо“, одржан у центру Шумадије:

„Протест перача шофершајбни у Крагујевцу привукао је пажњу јавности. Иако кажу да не раде ништа нелегално и имају подршку грађана, пре свих возача, у крагујевачкој полицији немају милости према њима - надлежни истичу да се закон мора поштовати. Протестом, који су одржали пре неколико дана на једној од најпрометнијих раскрсница у Крагујевцу, перачи прозора на аутомобилима хтели су да привуку пажњу јавности, како би њихов проблем био решен.

Паролом 'Хоћемо да радимо, нећемо да крадемо' послали су поруку надлежнима да их не кажњавају и да им дозволе да поштено зарађују.

Док у Полицијској управи Крагујевац кажу да се закон мора поштовати и нема рада на 'црно', возачи углавном подржавају пераче шоферки у Крагујевцу и кажу да им не сметају, јер нису нападни.

32 http://www.glas-javnosti.rs/clanak/hronika/glas-javnosti-10-08-2011/ulicni-perac-napao-i-udariosaobracajca

${ }^{33}$ Јаначковић, Б. (2018) „Несвакидашњи инцидент: путник градског аутобуса завршио на очној клиници, попрскали га перачи шофершајбни“, „Блиц“, 22. мај. О томе и у чланку: К., Д. (2018) „Прскали путнике у аутобусу течношћу за прање - један Нишлија на Очној клиници“, Народне новине, 23. мај, стр. 9. 
На три централне раскрснице у граду око двадестак Рома на овај начин је до сада издржавало своје породице. Како кажу, дневно могу да зараде од 500 до 2.000 динара, нема правила. Међутим, у последња два месеца полиција их интензивно приводи и кажњава, а казне се крећу од 10 до 50 хиљада динара... Док је искусна екипа перача стакала протествовала, и у глас викала 'Оћемо да радимо, нећемо да крадемо', возачи су их поздрављали, одјекивале су сирене... Сви су им махали, пружали руке, аплаудирали.“" ${ }^{\text {“4 }}$ (Слика 5 и Слика 6)

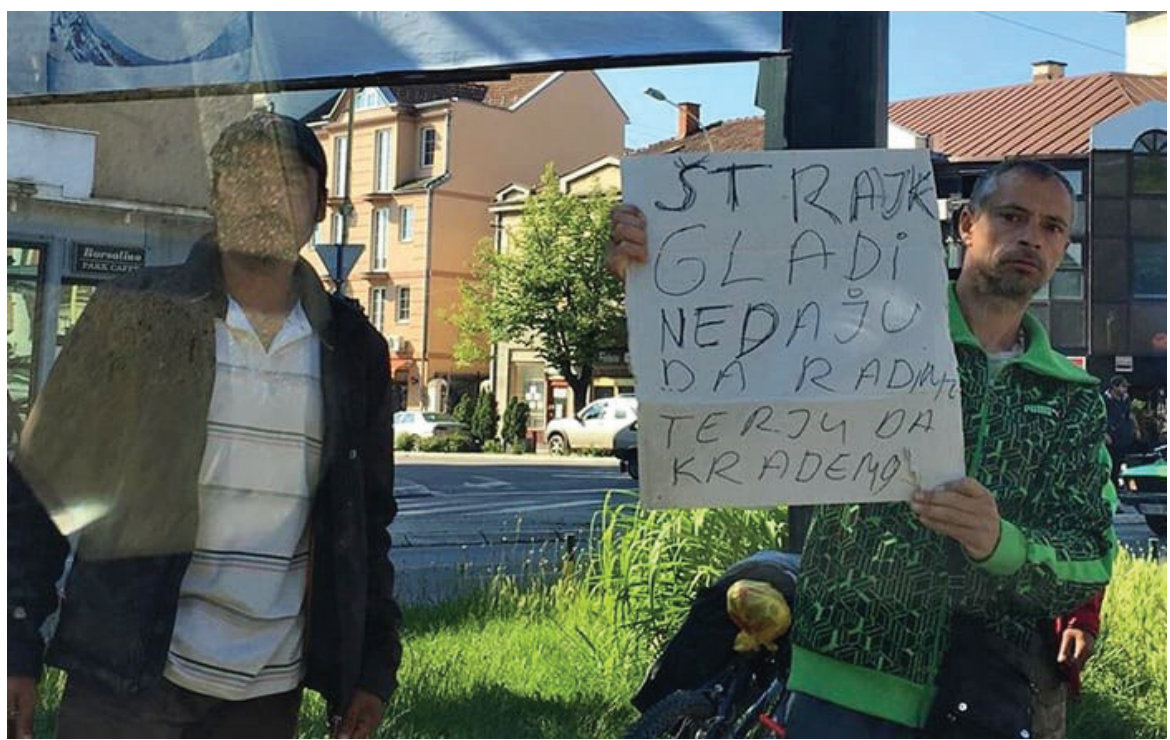

Слика 5: „, 'Оћемо да радимо, нећемо да крадемо“"

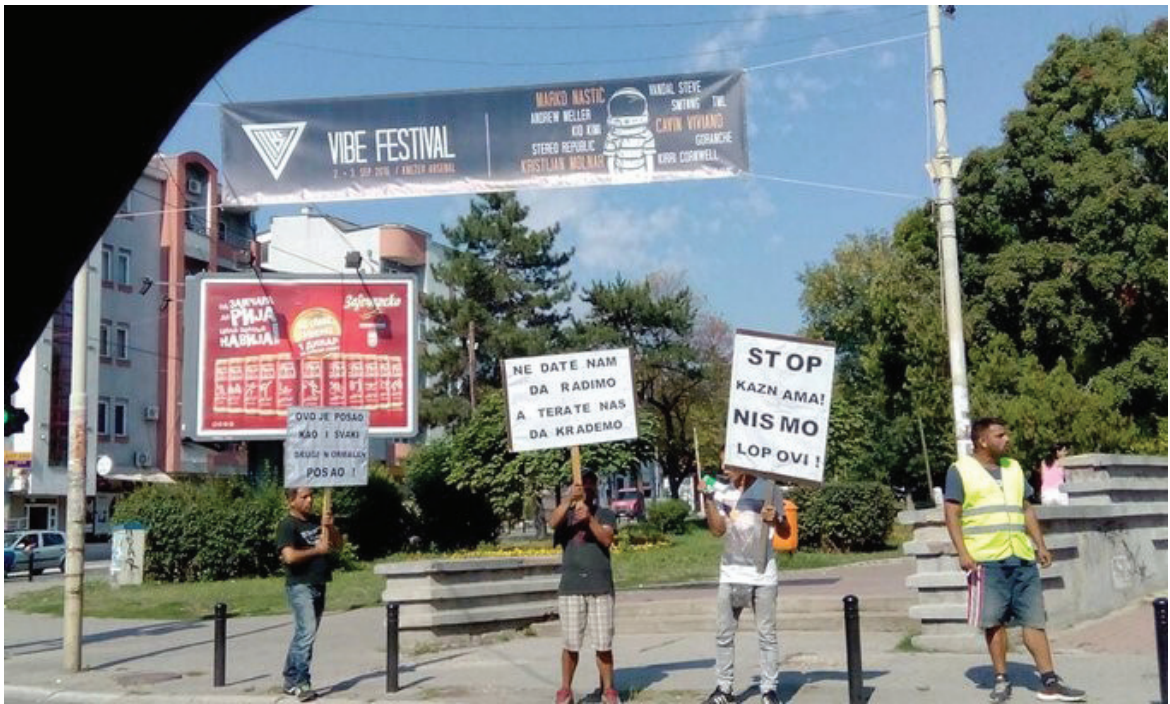

Слика 6: Штрајк крагујевачких шофершајбновача

\footnotetext{
${ }^{34} \mathrm{http}: / /$ www.logisticmagazin.com/?p=14066
} 
Штрајкачи веома разумно образлажу своју акцију:

„Перем шоферке већ неколико година и мислим да је ово поштен посао. Не крадемо, трудимо се и не смарамо возаче. Ко хоће - хоће и плати колико жели. Од овога се издржавамо и не видим на који начин ћемо убудуће зарађивати - каже један од перача шофершајбни (аноним).“ - „Ја од седме своје године перем шофершајбне... Сада имам 41. годину, али почели су да нам пишу казне... Двоје су и ударили, када су хтели да нас склоне. Никада нисам опрао стакло на силу, а почели су да нас бију. Приђем, питам, оперем, и ко како части. .. Имам четири сина, сви уче школе, иду редовно. Жена не ради, она је расељено лице. Људи који пролазе и знају ме, доносе ми ствари, одећу, и патике и за мене и за децу. Стану колима, дају нам, и оду. Нико се не жали што перем стакла. Али, полицији сметамо, а и њима смо прали кола. Не крадемо, радимо то што можемо. Писали су нам казне, од пет до 20.000 динара. На крају ћемо да идемо у затвор, да одробијамо то, јер паре немамо, каже Решит Бахтири.“- „Арсеровски Бегани каже да ради већ 10 година на семафору: 'Не дају нам да радимо, пишу казне... Кажу да деца морају у школу, а одакле да их школујемо. Шта да радимо, да ли треба да крадемо? Има нас око 20 у граду, распоређени смо по главним раскрсницама... Боримо се да прехранимо децу. Ето, ја сам механичар, завршио сам средњу школу, али нико ме неће, јер немам радно искуство. Цео живот проведох овде са сунђером и кофом, на прању стакла. Сваког дана се боримо за живот, за леба... Ако смо ми највећи проблем у држави, онда нека нас хапсе. А ми знамо да нисмо. .. Уместо да нам помогну, пишу казне', каже Бегани. “"35

И, напослетку и на почетку, закључимо да у том мноштву перача предњих и задњих стакала на лимузинама, видели смо, има:

- неснађених брисача шофершајбни,

- неуких семафорџијском занату,

- мусаве дечице којима није место на раскршћима,

- „перача“ који су заправо пасивни просјаци,

- оних агресивних и некултурних,

- одрпанаца,

- малолетних делинквената, и

- иних неваљалаца од сорте...

\section{Завршна напомена}

Закључујемо у једну реч. Разумевање егзистенцијалног стања и делатности тзв. урбаних рудара не значи тек просто „социолошко оправдање“. Иако их се само овлаш дотичемо у социолошком портретисању Томе Семафорџије, очекујемо да ће наше изучавање перача шофершајбни подстаћи скрупулознија емпиријска истраживања ромских урбаних рудара, осталих маргиналаца и губитника - не заборавимо - људи који животу дају лепше нијансе, „сиромашку чаролију“з6 $u$ установљьвање Социологије беде и пауперизаиије. ${ }^{37}$

\footnotetext{
${ }^{35} \mathrm{http} / / /$ www.logisticmagazin.com/?p=14066

${ }^{36}$ Луј-Фердинанд Селин (Céline), према нашем сазнању, први је употребио ту синтагму.

${ }^{37}$ Није се далеко одмакло од раног покушаја Мирослава Радовановића у књизи Социологија
} 


\section{Литература}

Andrejić, B. 2020. „Semafor(i) (kod Hiltona)”, Danas, 22-23. februara, str XVI.

Аноним. 2018. „Да ли знате? Ко је измислио аутоматски семафор“, Политика, 29. март, стр. 30.

Буквић, Д. 2009. „Три цене прслука на истој раскрсници“, Политика, 15. децембар, стр. 12.

Vuković, M., Todorović, D. 2020. Osnovi sociologije. Niš: Filozofski fakultet.

Guliani, R. W., Kurson, K. 2002. Leadership. New York: Hyperion.

Đorđević, D. B. (1998) „Interkulturalnost versus getoizacija i diskriminacija: slučaj Roma“, y: Rasizam i ksenofobija. Beograd: Forum za etničke odnose.

Ђорђевић, Д. Б. 2010. На коњу с лаптопом у бисагама: увод у ромолошке студије. Нови Сад, Ниш: Прометеј, Машински факултет.

Ђорђевић, Д. Б. 2013. Скинхеди: момц̧и из намег краја. Нови Сад: Прометеј.

Ђорђевић, Д. Б. .2018. Питао сам малог пужа (Моја социолошка прича о Шабану Бајрамовићу). Београд, Ниш: Службени гласник, Машински факултет.

Ђорђевић, Д. Б. 2019. „Тома Семафорџија““, Социолошки преглед LIII(4): 1636-1653.

Ђорђевић, Д. Б. 2020. „Урбани рудари Србије: социолошке цртице“, реферат на међународној научној конференција Социолошка наука, филозофско и научно знање у функиији прогреса. Никшић: Филозофски факултет.

Đorđević, D. B., Todorović, D. and L. Milošević. 2004. Romas and Others - Others and Romas: Social Distance. Sofia: Ivan Hadžisky.

Ђорђевић, Д. Б., Тасић, М. 2015. „Запис о занатима и занатлијама“, у: Рад, техника и етика у ери глобализащије. Ниш: Машински факултет, ЈУНИР.

Ђорђевић, Д. Б., Тодоровића, Д. 2020. Тома Семафориија: соииолошки портрет перача шофершајбни. Нови Сад, Ниш: Прометеј, Машински факултет (у припреми).

Janačković, B. 2009. „Teško su živeli, nosili smo je na stolici po dokumenta. Majka stradala u jezivom požaru u Nišu, njenom sinu izgorelo lice“", Blic, str. 1.

К., Д. 2018. „Прскали путнике у аутобусу течношћу за прање - један Нишлија на Очној клиници“, Народне новине, 23. мај, стр. 9.

Капор, М. 2018. „Наши у белом свету“, Политика, 28. јануар, стр. 21.

Љубичић, М. 2019. „Маргинализоване групе и савремени свијет“, Соичиолошки преглед LIII(4): 1438-1443.

Љутић, Ј. Д. 2012. „Како је бити перач шофершајбни са градских улица”, 26. марта објављено на сајту http://www.novosti.rs/vesti/beograd.74.html:372605-Kako-jebiti-perac-sofersajbni-sa-gradskih-ulica.

Минић, 3. 2018. „Кампања“, Политика, 11. фебруар, стр. 6.

М., О. (2018) „Потврђен програм инвестиција, 'Горици’ јемство“, Народне новине, 22-23. децембар, стр. 4.

беде и пауперизащије (1983), а већ се говори о томе „да је социологија маргинализованих група релативно скоро утемељена у домаћим оквирима“ (Љубичић, 2019: 1439). 
Оташевић, Бранка. 2008. „Не само елегија“ ( http://www.politika.rs/sr/clanak/56485/\% D0\%9D $\%$ D0\%B5\%D1\%81\%D0\%B0\%D0\%BC\%D0\%BE- $\%$ D0\%B5\%D0\%BB\% D0\%B5\%D0\%B3\%D0\%B8\%D1\%98\%D0\%B0, Политика, 20. септембар).

Попис становништва, домаћинстава и станова 2011. године: класификаичја занимања 2011. Београд: Републички завод за статистику РС.

Radovanović, M. 1983. Sociologija bede i pauperizacije. Gornji Milanovac: Dečje novine.

R., M. 2016. „On je najvoljeniji perač šoferki u Srbiji: Mušterije ga oblače, a njegovoj deci kupuju knjige!““ (http://www.telegraf.rs/vesti/2169896-on-je-najvoljeniji-peracsoferki-u-srbiji-musterije-ga-oblace-a-njegovoj-deci-kupuju-knjige-foto, 31. Maj).

Семафор (Саобраћај), Википедија, гледано 12. јануара 2019.

С., М. 2017. „Дечаци који перу шофершајбне све безобразнији - изнуђују новац“ (http://www.gradjanin.rs/decaci-koji-peru-sofersajbne-sve-bezobrazniji-iznudjujunovac/, субота 14. септембар).

Tairović, Z. 2015. „Kritička misao - promena imidža Roma“, y: Nacionalni saveti nacionalnih manjina i kultura (2). Novi Sad: Zavod za kulturu Vojvodine.

Todorović, D. 2008. „Šaban Bajramović - (B)Luzer južne pruge“, y: Kralj romske pesme (Drugi o Šabanu Bajramoviću). Niš: Punta.

\section{Интернет извори}

http://www.politika.rs/sr/clanak/56485/\%D0\%9D\%D0\%B5-\%D1\%81\%D0\%B0\%D0\%B C\%D0\%BE\%D0\%B5\%D0\%BB\%D0\%B5\%D0\%B3\%D0\%B8\%D1\%98\%D0\%B0

http://www.logisticmagazin.com/?p=14066

http://www.glas-javnosti.rs/clanak/hronika/glas-javnosti-10-08-2011/ulicni-perac-napaoi-udario-saobracajca

http://mondo.rs/a159090/Info/Drustvo/Da-t-operem-kola-VIDEO-prica-o-peracima.html http://www.radiocity.rs/program/projekti/pravo-na-pravo/deca-uluce/1664/borba-zaegzistenciju-ili-radna-eksploatacija.html

http://www.gradjanin.rs/decaci-koji-peru-sofersajbne-sve-bezobrazniji-iznudjuju-novac/

http://ritamgrada.rs/kragujevac/vesti/peraci-sofersajbni-ne-daju-nam-da-radimo-teraju-da krademo/

http://spit.ca/index.main.html

https://www.nytimes.com/2010/10/04/nyregion/04squeegee.html

https://nypost.com/2015/07/19/squeegee-man-is-citys-latest-blast-from-the-past/

https://nypost.com/2014/08/07/squeegee-men-are-back-and-terrorizing-city-streets/ 
Dragoljub B. Đorđević

\section{FURTHER SOCIOLOGICAL NOTES ON SQUEEGEE MEN}

Abstract: This study is one of the results of investigating the habits of Tomislav Asanović, a Roma squeegee man working on the crossroad near the Mladost Bridge in Niš, whom we renamed Toma the Traffic Light Man. The empirical part of this study was conducted in 2018 by Jelena Dinić, Dragan Todorović, and Mladen Mitrović, while the author of this text has nearly every day observed and collected data on the working habits of this squeegee man, which can be seen as an ideal representative of his guild. We are extensively using the documented material to present the attitude towards the Roma squeegee man, the so-called urban miners, whereas the category of urban miners also includes: carriers, the homeless, waste collectors, people who collect leftovers on graveyards and from dustbins, collectors of old paper and boxes, shoeshiners, sellers of small artefacts (costers), beggars, old iron collectors, collectors of plastic bottles and all sorts of plastic, landfill scavengers, cart drivers, buskers. Even though they are barely touched upon in this sociological portrait, it is expected that our study into squeegee men will incite more scrupulous empirical research into Romani urban miners, other marginalized people and losers - let us not forget - those who provide life with more beautiful nuances, and establish the sociology of misery and pauperization or the sociology of marginalized groups, a special discipline currently emerging in Serbian sociology.

Key words: Squeegee men, urban miners, Serbian Roma, Roma-related stereotypes 